\title{
FAKTOR USIA, JENIS KELAMIN, DAN JENIS CAIRAN \\ PADA KEJADIAN FLEBITIS DI RUANG RAWAT INAP PENYAKIT DALAM
}

\author{
${ }^{1}$ Rudi Kurniawan, ${ }^{2}$ Asep Gunawan, ${ }^{3}$ M. Andri Syafruddin \\ ${ }^{1,2,3}$ STIKes Muhammdiyah Ciamis \\ akhrud2008@yahoo.com
}

\begin{abstract}
Abstrak
Tujuan penelitian adalah untuk mengidentifikasi gambaran faktor usia, jenis kelamin, dan jenis cairan pada kejadian flebitis di Ruang Rawat Inap Penyakit Dalam RUSD Kabupaten Ciamis. Desain penelitian menggunakan desain deskriftif. Penelitian dilaksanakan pada priode bulan Mei-Juni 2016 dengan jumlah populasi sebanyak 66 responden. Angka kejadian flebitis pasien rawat inap yang memenuhi kriteria yaitu sebanyak 32 orang $(48,5 \%)$. Menurut faktor usia sebanyak 19 orang $(59,4 \%)$ termasuk usia lansia ( $>55$ tahun), menurut faktor jenis kelamin sebanyak 23 orang $(71,9 \%)$ perempuan, menurut jenis cairan yaitu sebanyak 27 orang $(84,4 \%)$ termasuk yang mengunakan cairan isotonik. Kejadian flebitis di Ruang Rawat Inap Penyakit Dalam RUSD Kabupaten Ciamis Priode Mei-Juni 2016 lebih cenderung terjadi pada usia lansia, berjenis kelamin perempuan, dan mengunakan cairan isotonik.
\end{abstract}

Kata Kunci: Flebitis, usia, jenis kelamin, jenis cairan

\begin{abstract}
The purpose of this study was to identify the description of age factor, sex, and type of fluid in the incidence of phlebitis in the Inpatient Room of Rusd Disease in Ciamis Regency. The research design uses descriptive design. The study was conducted in the period of MayJune 2016 with a population of 66 respondents. The number of phlebitis incidence of inpatients who meet the criteria that is as many as 32 people (48.5\%). According to the type of fluid, there were 27 people (84.4\%), including the age of elderly (> 55 years) which uses isotonic fluid. Incidence of phlebitis in the Inpatient Room Internal Disease RUSD Ciamis Regency Priode May-June 2016 is more likely to occur at the age of the elderly, female sex, and use isotonic fluid.
\end{abstract}

Keywords: phlebitis, age, sex, type of fluid

\section{PENDAHULUAN}

Terapi intravena atau yang biasa disebut dengan terapi infus merupakan metode yang efektif untuk mensuplai cairan, elektrolit, nutrisi, dan obat melalui pembuluh darah (intravaskular). (Potter \& Perry, 2013). Penelitian Brigman Young University tahun 2014 menunjukan tingkat kejadian flebitis $5,79 \%$ dari 432 pasien (Zarate, 2014). Flebitis akan menimbulkan banyak kerugian di antaranya adalah lama hari perawatan bertambah panjang, penderitaan bertambah,dan biyayapun akan meningkat (Depkes, 2015)

Tujuannya yaitu untuk mengidentifikasi gambaran faktor usia, jenis kelamin, dan jenis cairan pada kejadian flebitis di ruang rawat inap penyakit dalam RSUD Kabupaten Ciamis. Manfaat Hasil penelitian ini dapat menambah khasanah dalam pengembangan ilmu pengetahuan khususnya ilmu kesehatan dan keperawatan terutama yang berkaitan dengan flebitis.

Faktor yang menyebabkan terjadinya 
flebitis di antaranya adalah infiltrasi kimia maupun mekanik yang di tandai dengan adanya kemerahan, nyeri, panas, bengkak dan perubahan fungsi. Beberapa faktor yang terlibat dalam patogenesis flebitis, antara lain : (1) faktor kimia seperti obat dan atau cairan yang rentan mengakibatkan iritian; (2) faktor mekanis seperti bahan, ukuran kateter, lokasi dan lama kanulasi; (3) agen infeksi. Faktor yang memengaruhi angka kejadian flebitis mencakup: usia, jenis kelamin, dan penyakit menyebabkan kerentangan peradangan pada pembuluh darah (Yunand, 2014).

\section{METODE PENELITIAN}

Jenis penelitian adalah deksriptif dengan populasi adalah pasien yang terpasang infus Intravena dirawat di ruang rawat inap penyakit dalam bulan Mei-Juni 2016. Total sampel adalah 66 orang pasien dengan ukuran sampel sebanyak 30 orang. Teknik pengumpulan data yang digunakan peneliti dengan observasi. Penelitian menggunakan instrumen berupa lembar observasi untuk variabel dan sub variabel kejadian flebitis. Prosedur penelitian menggunakan studi pendahuluan tentang kejadian flebitis, studi pustaka dan mendapatkan izin untuk melakukan penelitian. Pengolahan data yaitu menggunakan editting data, coding, dan entry data. Pada penelitian ini mengunakan analisis univariat.

\section{HASIL PENELITIAN}

Distribusi Frekuensi Kejadian Flebitis di Ruang Rawat Inap Penyakit Dalam

Tabel 1. Kejadian Flebirtis pada Responden

\begin{tabular}{lcc}
\hline $\begin{array}{c}\text { Kejadian } \\
\text { Flebitis }\end{array}$ & F & $\begin{array}{c}\text { Presentase } \\
\text { (\%) }\end{array}$ \\
\hline Flebitis & 32 & 48,5 \\
\hline Tdk Flebitis & 34 & 51,5 \\
\hline \multicolumn{1}{c}{ Jumlah } & 66 & 100 \\
\hline
\end{tabular}

Pada tabel 1. dapat diketahui frekuensi kejadian flebitis pada pemasangan infus di ruang rawat inap penyakit dalam RSUD Kabupaten Ciamis pada tanggal 6 Mei - 4 Juni yang mengalami flebitis sebanyak 32 orang $(48,5 \%)$ dan tidak flebitis sebanyak 34 orang $(51,1 \%)$ dari total 66 pasien.

\section{Distribusi Frekuensi Kejadian Flebitis Menurut Usia}

Tabel 2. Kejadian Flebitis Menurut Usia

\begin{tabular}{ccc}
\hline Usia & F & $\begin{array}{c}\text { Presentase } \\
\text { (\%) }\end{array}$ \\
\hline Remaja & 4 & 12.5 \\
\hline Dewasa & 9 & 28.1 \\
\hline Lansia & 19 & 59.4 \\
\hline Jumlah & 32 & 100 \\
\hline
\end{tabular}

Pada tabel 2. dapat diketahui frekuensi kejadian flebitis pada pemasangan infus dilihat dari faktor usia sebagai besar yaitu sebanyak 19 orang $(59,4 \%)$ termasuk usia lansia (>55 tahun) dan sebagian kecil sebanyak 4 orang $(12,5 \%)$ termasuk usia remaja (14-20 Tahun).

\section{Distribusi Frekuensi Kejadian Flebitis Menurut Jenis Kelamin}

Tabel 3. Kejadian Flebitis berdasarkan jenis kelamin

\begin{tabular}{lcc}
\hline Jenis Kelamin & F & $\begin{array}{c}\text { Presentase } \\
\text { (\%) }\end{array}$ \\
\hline Laki-laki & 9 & 28,1 \\
\hline Perempuan & 23 & 71,9 \\
\hline \multicolumn{1}{c}{ Jumlah } & 32 & 100 \\
\hline
\end{tabular}

Berdasarkan tabel 3 dapat diketahui frekuensi kejadian flebitis pada pemasangan infus dilihat dari faktor jenis kelamin sebagian besar yaitu perempuan 23 orang $(71,9 \%)$ dan laki-laki 9 orang $(28,1 \%)$ 


\section{Distribusi Frekuensi Kejadian Flebitis Menurut Jenis Cairan}

Tabel 4. Kejadian Flebitis berdasarkan jenis cairan infus.

\begin{tabular}{ccc}
\hline Jenis Cairan & F & $\begin{array}{c}\text { Presentase } \\
\text { (\%) }\end{array}$ \\
\hline Isotonik & 27 & $84.4 \%$ \\
\hline Hipertonik & 4 & $12.5 \%$ \\
\hline Hipotonik & 1 & $3.1 \%$ \\
\hline Jumlah & 32 & 100 \\
\hline
\end{tabular}

Pada tabel 4. dapat diketahui frekuensi kejadian flebitis pada pemasangan infus dilihat dari faktor jenis cairan sebagian besar yaitu sebanyak 27 orang $(84,4 \%)$ termasuk mengunakan cairan isotonik dan sebagian kecil sebanyak 1 orang $(3,1 \%)$ yang mengunakan cairan hipotonik.

\section{PEMBAHASAN}

Hasil penelitian yang dilakukan oleh Satriani (2011) tentang faktor-faktor yang berhubungan dengan kejadian flebitis pada terapi cairan intravena di RS. Ibnu Sina Makassar dengan kejadian flebitis 28 orang $(35,4 \%)$ dari 79 orang., Pada penelitian ini kejadian phlebitis sebanyak 32 orang $(48,5 \%)$ dari 66 orang. Sesuai dengan teori Infusion Nursing Society (INS) tahun (2013), flebitis merupakan peradangan pada tunika intima pembuluh darah vena, peradangan ini didapatkan dari mekanisme iritasi yang pada edhothelium tunika intima vena dan perletakan trombosit pada area tersebut

Hasil penelitian yang dilakukan oleh Satriani (2011) tentang faktor-faktor yang berhubungan dengan kejadian flebitis pada terapi cairan intravena di RS Ibnu Sina Makassar dengan hasil $(43,9 \%)$ pada usia $>55$ tahun. Sesuai dengan teori bahwa usia merupakan tingkat perkembangan yang dijadikan ukuran kemampuan individu dalam beraktivitas dan sesuai dengan fungsi fisiologis. Usia remaja (12-20 tahun), usia dewasa (21-55 tahun) dan lanjut usia (>55 tahun).
(Depkes, 2013).

Hasil penelitian yang dilakukan oleh (Satriani, 2011) tentang faktor-faktor yang berhubungan dengan kejadian Flebitis pada terapi cairan intravena di RS. Ibnu Sina Makassar dengan hasil $(53,2 \%)$ yang mengalami flebitis pada perempuan. Sesuai dengan teori bahwa pembuluh darah berjenis kelamin perempuan akan berbeda dengan pembuluh darah laki-laki. (Safiudin, 2013). Sebagaian besar pasien yang dirawat menggunakan cairan yang osmolaritasnya mendekati osmolaritas plasma atau isotonik seperti $\mathrm{NaCl} 0,9 \%$, RL,futrolit,D5. Secara teori yang menyebabkan kejadian flebitis adalah cairan hipertonik sedangkan pada penelitian ini presentase kejadian flebitis terjadi pada cairan isotonik karena sebagian besar pasien yang di rawat mendapat terapi cairan isotonik.

Berbeda dengan hasil penelitian yang dilakukan Satriani (2011) tentang gamabaran kejadian flebitis faktor-faktor yang berhubungan dengan kejadian Flebitis pada terapi cairan intravena di RS.

\section{KESIMPULAN}

Distribusi kejadian flebitis di ruang rawat inap penyakit dalam RSUD Kabupaten Ciamis priode 6 Mei-4 Juni 2016 yaitu sebanyak 32 orang (48.5\%) yang mengalami flebitis. Sebagian besar kejadian flebitis berdasarakan faktor usia yaitu sebanyak 18 orang (51.4\%) adalah usia lansia (>55 tahun). Kejadian flebitis berdasarkan faktor jenis kelamin yaitu sebayak 23 orang $(71,9 \%)$ berjenis kelamin perempuan.Kejadian flebitis menurut faktor jenis cairan infus yaitu sebanyak 27 orang $(84,4 \%)$ mengunakan cairan isotonik.

\section{SARAN}

Disarankan untuk rumah sakit dapat mengurangi prevalensi dampak negatif dan kejadian flebitis dengan meningkatkan kemampuan perawat dalam pemasangan kanula intravena. 


\section{DAFTAR PUSTAKA}

Depkes RI, (2015). Pedoman Pencegahan dan Pengendalian Infeksi di Rumah Sakit dan Fasilitas Pelayanan Kesehatan Lainya. Jakarta: Penerbit Depkes RI.

Depkes RI., (2013). Ilmu Kesehatan Anak FK UI RSUP Ciptomangun kusumo Updet in Neonatal infection di Diakses tanggal 29 Maret2016.

INS., (2013). Infusions Nursing Society. (internet) tersedia dalam http://www.ins.com.id. [diakes tanggal 27 Maret 2016].

Potter and Perry, (2013) Buku Ajar Fundamental Keperawatan Konsep, Proses Dan Praktek Edisi 4, Alih Bahasa Ranata Komala Sari. Jakarta: EGC.
Safiudin, (2013). Panduan Pencegahan Infeksi untuk Fasilitas Pelayanan Kesehatan dengan Sumber Daya Terbatas. Jakarta: Yayaan Bina Pustaka Sarwono Priwironhadjo.

Satriani, (2011). Faktor-faktor yang Berhubungan dengan Kejadian Plebitis pada Terapi Cairan Intravena. Yunand, (2014). Faktor-Faktor Yang Mempengaruhi Terhadap Terjadinya Flebitis Pada Pemasangan Infus Kanul Intravena Di Ruang Rawat Inap RSI Ibnu Sina Padang tahun 2014 (skripsi) tersedia dalam http://repositoryyunand.blogdetik.com [Diakses tanggal 26 Februari 2016].

Zarate, (2014). Tingkat Kejadian Plebitis(intenet) Tersedia dalam http:// zarate.com. [Diakes pada tanggal 27 Februari 2016]. 